\title{
SYMPLOKÉ Y METAXY. UNA RELECTURA DE LA IMAGEN EN PLATÓN Y ARISTÓTELES PARA UNA ANALÍTICA DE LA APARICIÓN DIGITAL ${ }^{1}$
}

Symploke and Metaxy. A reading of the image in Plato and Aristotle in order to analyse digital appearance

Rodrigo Zúñiga*

\section{Resumen}

El artículo examina dos concepciones de la imagen de la filosofía clásica, para ensayar una relectura de la aparición digital o "imagen-pixel”. De Platón se considera la idea de imagen como symploké de ser y no ser: la imagen, como una piel diáfana que acompaña a las cosas, se desprende, cual fina película, de las cosas mismas y puede ser inscrita sobre una superficie (tal es el rol del pintor). De Aristóteles se examina el concepto de lo diáfano, una potencia común a todos los cuerpos, la que opera como instancia intermediaria (metaxy) para la emergencia de lo visible. Ambas concepciones ayudan a comprender la radicalidad de la imagen digital, entendida como una modalidad inmanente del 'aparecer' que no se inscribe sobre ninguna superficie ni medio, llevándonos a pensar en la figura de un nuevo diáfano hipermedial (el pixel).

Palabras clave: Estética, Imagen, Aparición, Simulacro, Imagen digital.

\section{Abstract}

This article examines two conceptions around the image of classical philosophy, in order to rehearse a re-reading of the digital appearance or "image-pixel". From Plato, we consider the idea of the image as symploke of being and not being: the image, as a translucent skin that accompanies all things, comes off, like a fine film, from those same things, and can be inscribed on a surface (this is the role of the painter). From Aristotle, the concept of the diaphanous is examined, a common potency to everything, which operates as an intermediary instance (metaxy) for the emergence of the visible things. Both concepts help to understand the radical nature of the digital image, understood as an immanent modality of the 'appearance' that is not inscribed on any surface or support, leading us to think of the figure of a hyper-medial new diaphaneity (the pixel).

Key words: Aesthetics, Image, Appearance, Simulation, Digital image.

\section{LA IMAGEN COMO ENTRELAZAMIENTO (SYMPLOKÉ) Y RESTO DE SER}

Nuestra indagación comienza con un pasaje de El Sofista, de Platón. En él se condensan cuestiones fundamentales relativas a la imagen (eídolon), en términos

\footnotetext{
${ }^{1}$ Este artículo forma parte del proyecto Fondecyt $\mathrm{N}^{\circ} 11300116$, "De la piel fotográfica a la ultrapiel digital. Contribuciones para una analítica filosófica del 'aparecer' digital en el debate post-fotográfico contemporáneo".
} 
bastante próximos a los desarrollos que el autor ya había avanzado en el Libro X de $L a$ República. Pero los alcances de este pasaje resultan mucho más osados. Recordemos que en un caso como en otro, se trata de dilucidar la naturaleza de una prestigiosa potencia, dynámeos thauma (El Sofista, 233d ss.). Según teme Platón, esta potencia (se refiere a la mimética) se cierne como una amenaza real contra las pretensiones de la filosofia por abrazar la unidad del ser. De esta potencia enigmática hacen gala, para extravío de los incautos, tanto el espejo (y su símil artesano, el pintor) duplicando las apariencias del mundo fenoménico, como el sofista, aparentando tener toda clase de experticias. En ambos diálogos, pero especialmente en El Sofista, el asedio definitivo a la mimética llama como testigo a la imagen. Y no podría ser de otra manera. Si una cualidad ontológica ha de atribuirse a las imágenes, ésta será la de dar cuerpo a una anomalía fundamental: entreverar los órdenes del ser y del no ser, al punto de volverlos indisociables.

El pasaje de El Sofista a que nos referimos se encuentra justo antes del célebre "parricidio" de las tesis de Parménides (241d ss.). Los términos generales del diálogo resultan bastante conocidos. Se trata de "capturar" al sofista a fin de distinguirlo del filósofo y de rehuir toda confusión entre dos géneros en su apariencia tan cercanos $\mathrm{y}$, sin embargo, tan marcadamente disímiles ${ }^{2}$. El problema es que el sofista obliga a una guardia perpetua (Sof. 231 a): pocas veces resultó tan esquiva la cualidad más propia de una naturaleza o género por definir, como si jugara a deslizarse entre otros géneros reconocibles, reflejándose en ellos de manera impostora, como un simulacro. Debido que la sofística, como la mimética, se oculta enconadamente en los inaccesibles refugios del no ser, regocijándose en la producción de imitaciones y "homónimos de realidades" (homónima tôn óntôn, 234b), una opción plausible de acorralamiento "de la bestia" (235b) consistiría en analizar, dividiéndola, la téchne que fabrica imágenes (tên eidôlopoikên téchnen). Para acceder al sofista, como vemos, hay que partir por las imágenes. ¿Puede haber un comienzo más temerario que ese? Esto supondría, por una vez, adentrarse en los parajes del no ser, en el límite mismo de la dialéctica filosófica. Y de hecho pareciera que, adelantando los primeros pasos más allá de la frontera, los vértigos y aturdimientos no concedieran ya ninguna tregua.

Con razón podríamos ver en este diálogo la primera gran ruptura antiplatónica alojada, antes que en ninguna otra parte, en el propio texto de Platón. Las tentativas por acorralar al sofista en su último refugio, el no ser, de inmediato se ven apresadas por sucesivas aporías. Si este asedio comienza por las imágenes, y si para ello se considera al sofista como un hacedor de imágenes (eidôlopoión), varias interrogantes, como un efecto boomerang, vienen al asalto (Sof. 239d). Apenas acordada esta estrategia, el Extranjero de Elea deja caer de inmediato posibles objeciones: ¿a qué se llamaría imagen, eídolon: a las imágenes reflejadas sobre el agua o los espejos, o a las

\footnotetext{
${ }^{2}$ Una tentativa recurrente en los textos de Platón. Bastará recordar las magistrales discusiones introductorias de dos de los diálogos anteriores dedicados a los sofistas: Protágoras (311e, 313c) y Gorgias (453 a, 455 a, 456 a).
} 
imágenes pintadas? ¿Acaso los ciegos no acceden a la experiencia de las imágenes, retrucaría sin rubores el sofista? En síntesis: ¿qué unidad veríamos en la pluralidad de imágenes que existen en la naturaleza?

Aquí da inicio el pasaje que nos interesa, pasaje lleno de dudas, de vacilaciones e indecisiones, en el que fermentan, sin embargo, atrevidas concepciones filosóficas (Sof. 240 a-c):

TEETETO - ¿Qué definición daríamos, pues, de la imagen (eidolon), extranjero, sino llamarla "un segundo objeto semejante", copiado a partir del verdadero?

EXTRANJERO DE ELEA— Por "segundo objeto semejante", ¿quieres decir un objeto verdadero? ¿O qué quieres decir con "semejante"?

TEETETO - No uno verdadero, como es claro, sino uno que se asemeja (eoikós).

EXTRANJERO DE ELEA—Pero por verdadero ¿quieres decir "un ser real”? TEETETO - Por cierto.

EXTRANJERO DE ELEA- ¿Y qué? ¿por no verdadero, quieres decir lo contrario de verdadero?

TEETETO— ¿Y cómo no?

EXTRANJERO DE ELEA — Lo que se asemeja es, pues, para ti, un irreal no ser (ouk óntôs ouk on), puesto que afirmas lo no verdadero.

TEETETO - Hay cierto ser, sin embargo.

EXTRANJERO DE ELEA - Pero no un verdadero ser, según tú.

TEETETO-Quizás no, pese a que hay un real ser de semejanza (eikôn óntôs)

EXTRANJERO DE ELEA-Así pues, ¿lo que llamamos semejanza (eikona) es realmente un irreal no ser (ouk on ara ouk óntôs estin óntôs)?

TEETETO - Tengo miedo [efectivamente] de que sea un entrelazamiento tal (symplokèn) el que enlaza el ser al no ser, de la manera más bizarra (Trad., mía).

La prevención final de Teeteto tiene el mérito de atraer y concentrar, en torno a un solo término, el rodeo lingüístico en que los pesquisidores se ven envueltos. Ese término es "entrelazamiento", symploké. En lo sucesivo, todo el diálogo entre Teeteto y el Extranjero de Elea estará volcado a destrabar ese lazo, a subdividir y analizar sus componentes, siguiéndolos y persiguiéndolos sin descanso hasta los menores recovecos, con tal de evitar que el lazo se vuelva un nudo ciego. En ese esfuerzo, encaminado en definitiva a hacer sitio al no ser como condición necesaria para una nueva ontología, se va construyendo uno de los escritos más extraordinarios de la filosofía clásica.

Nuestro afán en relación con este pasaje es bien restringido. Por ahora basta con recordar que ese lazo, o entrelazamiento, symploké, tiene lugar en la imagen, eídolon. Primera pista sustantiva para Platón: eídolon equivale a un modo de symploké. Claro que a un modo aberrante, bizarro (átopon).

Señalar, como hace Teeteto a manera de hipótesis, que la imagen es algo "que se asemeja" (eoikós) a otra cosa, supone advertir en ella, constitutivamente, un núcleo 
de no ser. "Un irreal no ser" (ouk óntôs ouk on) será la fórmula provisoria que propondrá el Extranjero en su intercambio con Teeteto. Y este acotará de vuelta: "All' esti ge mên pôs", "hay cierto ser, sin embargo", "hay algo" (esti), pese a todo. Y añadirá, poniendo acento en lo paradójico del caso: "hay un real ser de semejanza" (eikôn óntôs). Con otras palabras, el enigma filosófico que representa la imagen, dice relación con la lógica del entrelazamiento que ella misma anuda y que por ella solamente se sostiene. En la imagen toma cuerpo y se sustenta una inestabilidad ontológica fundamental. La imagen, eidolon, articula un anudamiento inesperado, un enlace manifiestamente ilógico, un pasaje que no debiera abrir paso, entre el ser y el no ser. De la imagen cabría decir, con Platón, que solo por ella accedemos a cierta residualidad ontológica, o sea, a la paradoja de un resto de ser.

\section{LA IMAGEN COMO PIEL DIÁFANA DE LAS COSAS. ALCANCES SOBRE LA SYMPLOKÉ PLATÓNICA}

2.1. En La República, Platón ya había aportado elementos para dimensionar los alcances de esta problemática. También del pintor (sôgráphos), ese demiurgo maravilloso, cabía decretar algo parecido. "Lo que hace no es real (ouk alêthê)", sentenciaba Sócrates. Y añadía enseguida: "pero, de algún modo, hace" (Rep. 596e).

Es cierto que en este caso la tensión estaba puesta en el extraño hacer de este artesano - cuya téchne se sitúa, sorprendentemente, dentro y fuera de la téchne-. Esta insólita téchne ek-téchnes gana, sin embargo, un nuevo protagonismo, cuando se lee a la luz del pasaje de El Sofista que citamos recién. El pintor ejecuta una acción ontológica extremadamente ambigua. Por eso es difícil saber "qué hace". Diríamos, siguiendo los términos de El Sofista, que pone en juego otra forma del entrelazamiento; al entrelazamiento ser / no ser, propia del eídolon, la acción pictórica añade el entrelazamiento téchne / ek-téchnes. Al trabajar la imagen, el pintor anuda todos esos factores; ambos enlaces se entrelazan. Por la vía de esta symploké, la acción del pintor pone en obra, "de algún modo", un "cierto ser", un resto de ser.

2.2. La explicación que Platón pone en boca de Sócrates, para dar cuenta de la mágica operación del pintor, ofrece el mayor interés para el argumento que estamos desarrollando. Ocupando el símil del espejo, advertirá primero que la prestigiosa potencia de la mimética reside en "producir todo [lo que existe]" (pánta gígnesthai, Rep. 596c s. Cf. Sof. 233d s.). Pero Sócrates ejercerá su rol correctivo. En rigor, si algo produce la mimética, es la apariencia-de-producir todo lo que existe ${ }^{3}$. Y los términos seguirán precisándose. Como sucede con un espejo, el pintor también "produce" todo, "pero toca un poco (apergásetai [...] smikron ti)" de cada uno (Rep. 598b). Y ese poco, remata el filósofo, es su imagen (eídolon).

\footnotetext{
${ }^{3} \mathrm{Y}$ desde luego que este entrelazamiento, entre poiesis y apariencia de poiesis, debe entenderse como otra variante del problema que estamos examinando.
} 
Sea este nuestro enunciado a trabajar: tocar la imagen. El pintor toca, de cada cosa, su imagen. Symploké del ser y el no ser, de la téchne y lo ek-téchnes, la operación del pintor conjuga ámbitos ontológicos dispares, y lo hace con total soltura. Ahora bien, ¿qué significa, en este contexto, “tocar”? ¿Cómo cabe entender este giro? Es claro que Platón hace referencia a una operación de extracción de índole peculiar. El pintor realiza una acción compleja, de raíz oscura, que llega a perturbar (trakhên) el alma, y que está emparentada con los embrujos (goêteías), la prestidigitación (thaumatopoiía) y los artificios (mêkhanás, Rep. 602d). Por ello, el acto mismo de pintar supone algo como desprender, de cada cosa, esa piel finísima que llamamos imagen, para luego transferirla "mágicamente" y depositarla en una superficie. Y esta superficie representa, en el imaginario platónico, el espacio donde se agolpan los fantasmas. La pintura es un rito de espectros que hace patente, al mismo tiempo, la condición espectral del mundo sensible.

2.3. Tenemos a nuestro haber, hasta aquí, tres ideas relacionadas:

a) La imagen como symploké de ser y no ser: en la imagen se anuda, inesperadamente, un resto de ser.

b) El pintor opera con la imagen, con la symploké de ser y no ser. Ese "operar", ese hacer anómalo, supone una symploké del orden de la téchne y de lo que excede la téchne (ek-téchnes).

c) Ese hacer consiste en tocar, en extraer de cada ente, su imagen.

Aún nos queda por agregar un cuarto giro. Este cuarto elemento (d) está relacionado con la naturaleza de la división "mágica", por así decir, que ejecuta el pintor, de la imagen respecto de la cosa.

Antes de anotar este cuarto giro, recordemos algo a título de premisa general. $\mathrm{Y}$ es el hecho de que, con el ánimo de rebajar y tener bajo control las ínfulas ontológicas de la imagen (y por ende de la mímesis), Platón se resiste a reconocerle otra cosa que una jerarquía residual en el orden del ser. Pero ello no impide su acoso persistente al proyecto platónico. Y ello al punto de obligarlo a reabrir la discusión cuando esta parecía ya zanjada (es el caso del Libro X de La República: una vez establecido el proyecto en los nueve libros precedentes, pareciera como si una súbita urgencia obligara a volver sobre este nudo sin resolver, representado por el arte, por la imagen y la ilusión). Esta obligación se expresa aún con mayor nitidez en la caza despiadada al ilusionismo mimético en ese portento filosófico que es El Sofista. ¿Cómo no habría de ser así? Lo que acá está en juego - Platón lo sabe biencompromete a toda la extensión de lo sensible. ¿Por qué? Porque la imagen no sigue a la Idea, no reconoce jerarquías. La imagen se ciñe a la extensión inmanente de lo sensible. Puesto de otro modo, la imagen acompaña estrechamente a las cosas y es esa su mayor impostura. Suplemento del ente, suplemento que fisura el ente, la imagen pone en evidencia el diferir de cada ente respecto de sí mismo: cada ente es él mismo más su imagen. Cada fenómeno difiere de sí mismo en su imagen epifenoménica. Al 
acuñar el término phántasma, simulacro, Platón establece una modulación ontológica fundamental. El phántasma designa, en cierta manera, no solo a la imagen misma (eídolon) como apariencia, sino al conjunto de los entes y de sus imágenes. En otras palabras, phántasma es un nombre que Platón emplea también para referirse al campo mismo de la objetividad: un campo de la muerte, un campo de lo muerto-vivo. Las cosas y sus imágenes, las cosas estrechamente cercadas por el resto de ser, surcan el campo de nuestra empeiría, de nuestra experiencia sensible siempre bajo sospecha.

Esta observación nos sitúa de lleno en el cuarto elemento (d) que queremos agregar. Volvamos sobre nuestras premisas: al pintor corresponde la acción mágica, propiamente especular, de separar a la cosa de su imagen. El pintor ejecuta esa extracción singular: toca, de cada cosa, un poco, su imagen — un resto de ser-. Y, en ese mismo movimiento, transfiere a otro lugar esa fina película aparencial que acompaña a la cosa. El pintor desprende y separa, transfiere y deposita sobre una superficie: en eso consiste su extraño hacer. Se trata de una acción epifenoménica que excede cualquier téchne: doblar la unidad de los entes, fisurar la mismidad, rozando las superficies y desprendiendo de ellas, en un verdadero golpe ontológico, el suplemento de ser que cada ente despide doblándose a sí mismo en su propia imagen, como nos lo revela el espejo. Es eso lo que hace el pintor, aduce Platón.

Podemos expresarlo de otra manera. Nuestra cuarta idea puede quedar así:

d) Lo que el pintor hace es trabajar sobre esa piel diáfana, de consistencia fantasmal, que recubre a las cosas.

El eídolon, un irreal no ser (Sof. 240c), un ser de semejanza que enlaza el ser al no ser (symploké), constituye - ya que el pintor lo toca y desprende, lo transfiere y adhiere a una superficie - un contacto. La imagen es algo "que se palpa" (es tarea del pintor "tocarla"), pero tiene consistencia inmaterial. Contacto oscuro, symploké que anuda lo sensible y lo intangible, lo material y lo inmaterial, la imagen se pliega sobre la cosa separándola de ella misma, pudiendo desplegarse asimismo por fuera de la cosa, en las superficies reflectantes, en las superficies pictóricas (de hecho son estas superficies las que 'activan' la separación). Ahí es donde se recoge la imagen y busca ganar autonomía. La superficie pictórica, recinto de los espectros, es ella misma una symploké, una zona mixta donde se enlazan los fantasmas y el mundo sensible.

Película diáfana que recubre a las cosas, transparencia sin densidad, envoltorio epifenoménico, la imagen, como toda piel, puede ser desprendida. El pintor, ya lo sabemos, transfiere mágicamente esa piel transparente, cuya singular naturaleza puede ser expresada en la figura de la symploké (entrelazamiento de ser y no ser). El pintor, en su transferencia mimética, modela esas pieles irreales, esos restos de ser, esas pieles de ultrapiel, sobre una superficie. Uno de los méritos de Platón radicará en convertir ese acto menor, mimético, en un enigma filosófico de magnitud mayor. Quizá por eso se juega, en torno a la imagen, la vocación definitiva del pensamiento platónico por el simulacro y la fantasmagoría. La pintura no será entonces un elemento accesorio, incidental. Platón, a su pesar, es un filósofo de lo sensible. Su 
seducción, su influencia sempiterna ${ }^{4}$, toman fuerza en esta inmanencia de lo sensible, en este sensible desbordado por sus imágenes, que cae sobre sí y se anuda sin afuera.

\section{EL APARECER DE LAS IMÁGENES. ARISTÓTELES Y EL ESPACIO INTERMEDIARIO (METAXY)}

3.1. Abramos este tercer apartado con una cita célebre:

(...) Y esto me llevó a reflexionar sobre la inimitable belleza de las imágenes de la pintura de la naturaleza que los lentes de vidrio de la cámara arrojan (...) Imágenes mágicas (fairy images), creaciones de un momento, destinadas rápidamente a desaparecer (...) Fue en el curso de estos pensamientos que la idea me vino a la mente (...) Cuán encantador sería si fuese posible provocar que estas imágenes naturales (natural images) se imprimieran ellas mismas de una manera durable (to imprint themselves durably) y permanecieran fijas en el papel (citado en Batchen, 34. Mi traducción).

Estas palabras, cuya entonación platónica no pasará inadvertida al lector, llevan la firma de William Henry Fox-Talbot ${ }^{5}$ (1969). Pertenecen al "Brief Historical Sketch of the Invention of the Art" con que el filólogo y botánico inglés acompañó su gran obra inaugural The Pencil of Nature, una vigorosa colección de calotipos, en 1844. Desde luego es mucho más que una entonación, o que un guiño platónico, lo que se deja ver en estos pasajes destinados a la presentación pública de su invento y a los exuberantes resultados que podía arrojar. La fotografia establece un estándar diferente para la transferencia mimética entendida en un sentido platónico. En la superficie fotográfica, la symploké se exhibe como automatismo del aparato tecnológico. El "ser de semejanza" impregna la superficie en un contacto a distancia. Pero a pesar de sus marcadas diferencias (en términos de ejecución, de modalidades de trabajo, de los radios de influencia cultural y de masificación, etcétera.), al menos en un punto, el de la transmisión de esa piel finísima que reviste a las cosas, la acción mágica del mimetés y la acción "automática" del aparato consienten una semejanza profunda. Con todo, hay que dejar sentada una diferencia fundamental. La fina película aparencial que la fotografía extrae de los cuerpos - como el pintor para Platón - se inscribe fisicamente sobre el soporte fotográfico, cavándolo de manera delicada, trazando una marca lumínica, una datación, que hacen de la fotografía un modo de superficie contactada como jamás pudo aspirar a serlo la pintura de ninguna época.

Ahora bien, lo relevante para nuestra argumentación es que la imagen (eídolon), esa piel transparente que enlaza ser y no ser, se inscribe de manera distinta dependiendo de la superficie que la acoja. Aquí también las diferencias entre pintura y

\footnotetext{
${ }^{4}$ Jean-François Mattei hace mención muy justamente de "la perennidad del ascendiente de Platón sobre todos quienes se entregan a los secretos de la imagen" (38). La traducción es mía.

${ }^{5}$ Para un análisis detallado de la investigación de Fox-Talbot en el contexto de los comienzos de la fotografía en el medio europeo, véase también Brunet (117-156) y Taylor.
} 
fotografia no pueden ser más manifiestas. Sus "espectros", por consiguiente, son distintos. En la fotografía se hace patente de un modo inédito el recurso a la historicidad, al duelo, de la conmemoración, al testimonio histórico. El eídolon, en tal sentido, adquiere cualidades fantasmáticas distintas en una y otra.

Dicho de otro modo, el medio material donde se agolpan las imágenesfantasmas determina también su "espectralidad".

El espectro pictórico no es del todo correspondiente con el espectro fotográfico. Pero si pensamos el problema desde una perspectiva más amplia —una perspectiva "medial"-, hay un antecedente que no debemos desatender. Nuevamente la filosofia clásica toma la palabra. Es la reflexión aristotélica, de hecho, la que aportó antecedentes fundamentales a propósito de la 'aparición' de las imágenes en un medio particular. Es cosa de pensar en la noción de metaxy (medio o intermedio $^{6}$ ). Emanuele Coccia tiene razón en reivindicar, leyendo a Aristóteles, la capacidad de las imágenes de apoyarse en el medio (por ejemplo en las superficies reflectantes) de un modo extraño, particular, no extensivo (Coccia 34-35). Aristóteles asigna al concepto metaxy una importancia fundamental para su teoría de la sensibilidad, de los cuerpos sensibles y de las imágenes. Un término, en particular, asumirá la condición paradigmática de la intermediación para pensar el 'aparecer' de las imágenes. Ese término es lo diáfano (to diaphanés).

3.2. ¿Qué dice Aristóteles sobre to diaphanés que nos resulta tan significativo? En "De la sensación y de los sensibles" ("Peri aisthesis kai aisthetón"), anota:

Lo que llamamos diáfano no pertenece en propiedad al aire o al agua, ni a otro de los cuerpos así denominados, sino que es una cierta naturaleza y fuerza común (tis esti koiné physis kai dynamis) que no existe separadamente, sino que está en esos cuerpos, y que reside [también] en los otros [cuerpos], más en estos, menos en aquellos" (439 a, mi traducción).

Lo diáfano, lo transparente, está presente en todos los cuerpos sensibles. En cada cuerpo reside esta naturaleza común que los vuelve visibles, objetos de una sensación. Lo diáfano no se reduce al aire o al agua, o a la luz: proviene del "cuerpo eterno situado en la región superior del universo" (Acerca del Alma II, 7, 418b, mi traducción), o sea, su "diafaneidad" coexiste con los cuerpos transparentes, pero al mismo tiempo los excede y determina. Ahora bien: si tiene la facultad de abrir el campo de lo visible, es porque no es visible él mismo por sí absolutamente (Acerca del Alma, II, 7, 418b, mi traducción), sino gracias a un color —el de los objetos-con

\footnotetext{
${ }^{6}$ Sin ánimo de un seguimiento de las ocurrencias del concepto metaxy en la filosofía griega antigua, convendrá recordar que en uno de los pasajes significativos del Teeteto platónico, aquel en que Sócrates y Teeteto buscan asimilar las doctrinas de Protágoras y Heráclito sobre la sensación (Teeteto 152c-155c), hay un empleo del término que bien pudiera alinearse con las futuras connotaciones aristotélicas: "Lo que decimos es que cada color no será aquello que se dirige al encuentro, tampoco lo encontrado, sino algo intermedio (metaxy ti) que se engendra para cada uno (...)" (Teeteto 154 a. Mi traducción).
} 
el que entra en contacto ${ }^{7}$. Cada objeto del mundo posee en sí mismo, entonces, la causa de su visibilidad, pues sus colores ponen en movimiento lo diáfano en acto ${ }^{8}$ (los colores y lo diáfano formando parte, ambos, del objeto). De ahí que, en palabras de Aristóteles, en cada cuerpo haya un límite dado para esta fuerza (De la Sens., 439b). Ese límite está constituido por la interacción específica entre el color determinado y lo diáfano. Lo diáfano, pues, activa el color de lo "sensible por accidente" (o sea el de tal o cual objeto) $\mathrm{y}$, al mismo tiempo, se pone él mismo en movimiento al ser "estimulado" por el color: "Es el movimiento que pasa por el intermediario (metaxy) el que hace ver" (De la Sens., 438 a). Se entiende, pues, cuál sea en definitiva el interés del Estagirita por promover la hipótesis de lo diáfano. En último término, apunta a ofrecer una respuesta consistente a la pregunta por la naturaleza del aparecer.

Las imágenes tienden a esparcirse. Se diseminan por todas partes, abarcan el horizonte del aparecer. Están conectadas por vía de lo diáfano, de lo transparente, de lo incoloro, es decir, de aquello que, encontrándose en potencia en todos los cuerpos, carece él mismo de consistencia corpórea. Sólo así se comprende que el intermediario no se vea restringido por las limitaciones o determinaciones de los cuerpos mismos. Aquí está la importancia de la tesis de lo diáfano y de su intermediación. Esta naturaleza "común" no se reparte ni se ve aminorada. Sólo lo diáfano puede hacer emerger el color donde quiera que este se manifieste. Potencia pura, sin disminución ni desagregación, espacio anterior que no se despliega en la duración, lo diáfano — pudiéramos decirrecubre con su invisibilidad el espacio abierto de los entes, lo cual significa que hay, por doquier, interacción inmanente entre lo diáfano y los colores contingentes de los cuerpos.

3.3. Es ahí, en lo diáfano, que se encuentra en todos los cuerpos, pero que al mismo tiempo los excede sin reducirse a ellos, donde habitan las imágenes que nos rodean y con las que nos relacionamos. Sin el medio, la sensación visual no sería posible. Lo diáfano es el nombre de la potencia del aparecer, del devenir sensible: medio en el que las imágenes se muestran y que a la vez provoca su aparición.

Por lo mismo, se trata de un medio harto peculiar. Ciertamente, como medio que es, supone una transformación, una pasión, un modo de padecer la materia "imagen". El medio "cambia" con la materia que es impresa en él. El punto es de qué manera cabe entender la "transformación" de lo diáfano como medio, en relación con su materia (las imágenes). Y esto porque lo diáfano opera como pura apertura de lo intermediario, apertura en la cual una cierta alteración ha de producirse -el devenir sensible de un cuerpo - sin que, por ello, el intermediario mismo deje de conservarse

\footnotetext{
${ }^{7}$ Tomás de Aquino (214), en el capítulo XIV del Libro II de su comentario a Acerca del Alma, señala que lo diáfano, al no poseer color propio, está sujeto a cualquier color "ajeno", siguiendo al cual se hace visible en cierta manera.

${ }^{8}$ Acerca del Alma, II, 7, 418 a.
} 


\section{Rodrigo Zúñiga}

como potencia. Puesto de otro modo, lo diáfano supone un espaciamiento intermediario cuya alteración accidental no incide, de ninguna manera, en una alteración de naturaleza. Esta característica lo convierte en un medio eminente, en un medio sui generis. Más todavía: quizá se trate de la primera noción hipermedial. $\mathrm{He}$ ahí su peculiaridad y su importancia para nuestro argumento. ¿Qué otra cosa decir de un medio que no solo abre el horizonte de lo visible, sino que además se mantiene en una pura apertura? ¿Cómo no señalar aquí, en este constructo aristotélico, uno de los dispositivos fundamentales desde los cuales nos damos a pensar, una y otra vez, el problema del medio y de su relación con las imágenes, desde una perspectiva contemporánea?

\section{SYMPLOKÉ Y METAXY. PARA PENSAR LA APARICIÓN DIGITAL}

4.1. Symploké y metaxy. Es aquí, en el arco que se tiende entre estos conceptos, representantes de dos concepciones de la imagen - la platónica y la aristotélica-, donde instalamos nuestro asunto. De Platón a Aristóteles leemos, retrospectivamente, los rudimentos de un debate contemporáneo. Lo singular del caso es que ese debate - en cierto modo sin precedentes - cobra características marcadamente platónicas y aristotélicas. Me refiero a una posible teoría del medio en la época digital.

Volviendo sobre Platón y Aristóteles, hablando de symploké y de metaxy, nos ubicamos en un espacio teórico de gran interés. Entre uno y otro, transitamos de una ontología del ser suplementario a una ontología del intermediario. Y es eso lo que requerimos para reflexionar sobre el pixel, la información numérico-binaria aplicada en la producción de imágenes digitales. Según hemos visto, a la tesis platónica sobre la imagen-simulacro, Aristóteles complementará la idea de que el aparecer de las imágenes descansa, a su vez, sobre una potencia común, lo diáfano (apartado 3, 3.2). Eso significa que lo diáfano constituye la primera transparencia: el fondo transparente desde el cual aparecen los entes del mundo, los cuales devienen, así, visibles y perceptibles (objetos de la sensación). Se diría — ya lo advertíamos - que lo diáfano constituye algo así como un hipermedio: el medio anterior a cualquier otro medio. El primer medio, el primer intermediario (metaxy), el espacio anterior en el que se entrelazan (symploké) los cuerpos sensibles y la potencia que los hace aparecer.

Ahora bien, aquella naturaleza de primer medio o de hipermedio, como es usual en Aristóteles, es elaborada en atención a un estatuto bien particular, tanto físico como ontológico. Lo diáfano existe en los cuerpos. Pero a su vez trasciende los cuerpos, pone en contacto los órganos sensoriales (los ojos, por ejemplo) con los colores de los entes. Las pasiones de los órganos generan las sensaciones de los humanos. Lo diáfano tiene, pues, una capacidad de movilizar, de poner en contacto, de generar pasiones, alteraciones físicas, sensaciones. Al mismo tiempo, su preeminencia ontológica dice relación con esa misma condición conectiva, productora de eventos sensibles. El aparecer mismo: tal sería el privilegio productor del hipermedio. 
La hipótesis aristotélica de lo diáfano, según nuestro punto de vista, nos pone en situación de ensayar una tesis general sobre el hipermedio en el contexto contemporáneo. Quizá tendríamos que pensar en un nuevo diáfano, en una modalidad distinta de la transparencia. La particularidad de este nuevo diáfano será, acaso, la de provocar el fin de los medios, la supeditación de los medios al hipermedio. Y por otro lado, la de suspender la inscripción material de las imágenes. Trataríamos con un hipermedio en el que no hay páskein (pasión) en el sentido aristotélico. La naturaleza de las imágenes sufriría una modificación de proporciones, casi una transustanciación. Se entiende a qué estamos apuntando. Posiblemente el pixel redefina, en el paisaje digital de nuestros días, los alcances de la tesis aristotélica de las imágenes y nos obligue a pensar en un estatuto de lo diáfano completamente diferente.

4.2. ¿Un nuevo diáfano? ¿Acaso también una nueva symploké, dependiente de un giro en la ontología de la imagen? En efecto, tal parece que hubiéramos sido abandonados por los phántasmas. No cedamos a la tentación de clamar el triunfo de los simulacros, ¿no se trataría más bien de su deserción? Tal deserción hallaría su causa más profunda en una época, la nuestra, que va haciendo desaparecer las superficies contactadas. La hermosa paradoja que emparentó, a pesar de sus diferencias, a la pintura y a la fotografía - alojar imágenes sobre una superficie, sobre una capa sensibilizada, y transitar la frontera entre lo material y lo inmaterial: en suma, dar cuerpo a la symploké - alcanzaría, con las imágenes-pixeles, un punto de no retorno. Estas imágenes desmaterializadas - aglomeraciones estructuradas de pixeles - no se encarnan, no contactan. Esta característica de las imágenes de síntesis amenaza los regímenes mediales. Con ellas nos adentramos en una época hiper-medial.

Mirado de esta manera, ¿de qué hablamos cuando hablamos de lo hipermedial? Diremos que el estatuto hipermedial conviene a un modo de metaxy en el que las imágenes no se inscriben "en un medio", sino que aparecen — se componen - en virtud de una potencia inmanente de numerización (la "composición digital"). Poco importa a este respecto si tratamos con una imagen obtenida por vía de un proceso fotográfico que luego se digitaliza, o con una imagen de síntesis. En un caso como en otro, y en todos los casos en que está en juego la traducción numérica de la luz, la estructura profunda de las imágenes se organiza en función de secuencias informáticas y de unidades discretas que, dependiendo de las resoluciones de los captores electrónicos o de la capacidad de los softwares, determinan el carácter de las apariciones sobre los monitores. Ahora bien, las tesis de Aristóteles nos sirven para comprender un aspecto importante de tal "carácter de las apariciones". Y es el hecho de que estas imágenes-pixeles son portadoras y productoras, ellas mismas, de su propio diaphanés.

¿A qué apunta esta argumentación? Al hecho de que cada imagen digital forma parte, en razón de su propia conformación en pixeles, de un campo más amplio: la secuencia prolongada ad infinitum de todas las imágenes digitales. Cada 
imagen digital existe en estado de apertura. Cada una de ellas configura un universo potencialmente ilimitado en sí mismo, pero al modo de mónadas que no se cierran sobre sí mismas, puesto que cada cual puede ser ensamblada con otras (como en un intercambio genético, o en una polinización genética), de manera que todas juntas, con su información transferible, forman parte de un objeto continuo imposible. Y este continuo digital del que hablamos constituye nuestro nuevo diáfano.

Las imágenes-pixeles aparecen; ese aparecer no es un simulacro, no duplica lo ya existente, no se trata de una piel desprendida. Las imágenes-pixeles se alojan en un espacio intermediario, pero no al modo de la metaxy aristotélica. El contraste entre transparencia y color se reduce al pixel, o sea, a información desmaterializada. El pixel estructura una imagen sin cuerpo, una imagen sin carne ni huella. Las imágenespixeles no se inscriben, se desplazan; siempre a punto de salirse, de ser transferidas o de ser transformadas, se establecen en un soporte que no es soporte, en una superficie que no es superficie, en un medio que no las fija para siempre. Ahí donde se alojan, en ese espaciamiento intermediario que las retiene en su temblor, siguen vibrando. Las imágenes-pixeles son ellas mismas su propio espaciamiento, su propia metaxy. Su modelización inmanente, su naturaleza matemática binaria, surte un doble efecto: de un lado esa inmanencia las homologa al resto de las imágenes-pixeles, y por otro lado las convierte en una mónada, en un universo particular y complejo. Cada mónada, cada imagen-pixel, aparece inmanentemente: sale de sí misma alojándose en sí misma, en la superficie líquida que ella misma configura con su aparecer, en la superficie líquida con la que comparte sus 'genes' numéricos, sus secuencias binarias, en el momento de su propia y conjunta aparición.

4.3. Por ello no es extraño que el continuo digital —esta especie de khôra platónica sin huella, sin negativo, sin inscripción - dé cuenta de una tendencia actual a la remisión de los regímenes mediales. En este nuevo diáfano digital no hay impresión, no hay pasión, no hay alteración de superficies, no hay espectros rondantes ni marcas espectrales. Hay apariciones, no espectros. Creíamos saber qué era una aparición, pues solíamos referirla, directa o indirectamente, al ámbito de los phántasmas, de las eídola, de los dobles. La imagen era el territorio de la symploké, del anudamiento atópico entre lo sensible y lo simulacral, entre lo material y lo inmaterial (apartados 1 y 2). Pero ahora nos las vemos con modulaciones, con frecuencias moduladas del continuo digital. Evidentemente podemos hablar, casi por necesidad del sentido común, del "medio" digital. Pero algo se ha transformado íntegramente cuando, en un momento determinado del devenir científico y tecnológico, irrumpe un lenguaje formal que ejerce una potencia de reducción inmanente de esta magnitud. Cuando el barrido digital puede integrar y traducir a lenguaje binario no sólo volúmenes espaciales o cromáticos, objetos, entes sensibles, etcétera, sino a los medios mismos, a las propias medialidades ahora digitalizadas - como si todas concurrieran y fueran a desembocar, al unísono, en la figura promisoria de un metaartista, el compositor 
digital - entonces, insistamos, se ha provocado una ruptura en la historia de los medios: el advenimiento del hipermedio. Remisión o extinción definitiva de los regímenes mediales, lo cierto es que este fenómeno general se aprecia con claridad en las propias imágenes-pixeles, esas pieles transparentes venidas de sí mismas, al mismo tiempo suplementarias e intermediarias, al mismo tiempo symploké y metaxy, formas desmaterializadas y diáfanas, recubiertas por su propia transparencia.

¿Qué significa que estas imágenes-pixeles no contacten, que no se desprendan de un original, y que en consecuencia no las podamos considerar, de acuerdo con una jerarquía que hizo las bases de la reflexión estética clásica meros restos de ser, residuos ontológicos, epifenómenos (Platón)? ¿Qué significa que estas imágenespixeles obliguen a una redefinición del carácter de la intermediación y del 'aparecer'? Quizá, en último término, hacemos frente aquí - ya lo decíamos - al agotamiento de los espectros. Y junto con ello, a una inédita forma-imagen en la que la luminosidad proviene "desde dentro", desde el propio pixel, generando un modo inmanente de aparición (la imagen-pixel), y por lo mismo un nuevo diáfano (el continuo digital) que determina, a su vez, un modo de lo sensible que le es correspondiente (un sensible digital, para cuya comprensión debiéramos recurrir a diversas prácticas fenomenológicas). De la "espectrología" de la imagen a la imagen-pixel que aparece desde sí misma, puro brillo pixelado no espectral, seguimos volcándonos, con la misma voracidad y ansia que los viejos filósofos, sobre territorios de vértigo y aturdimiento.

Universidad de Chile* Facultad de Artes

Manuel de Salas 211, Dpto. 205, Ñuñoa, Santiago (Chile) rodrigozunigacontreras@gmail.com

\section{OBRAS CITADAS}

Aristóteles. De l'Âme. Texte établi par A. Jannone, traduit et annoté par E. Barbotin. Paris: Les Belles Lettres, 2002.

_ 'De la sensation et des sensibles". Petits traités d'histoire naturelle. Texte établi et traduit par René Mugnier. Paris: Les Belles Lettres, 2010, 21-52.

Batchen, Gregory. Burning with desire. Massachusetts: The MIT Press, 1999.

Brunet, François. La naissance de l'idée de photographie. Paris: Presses Universitaires de France, 2012.

Coccia, Emanuele. La vida sensible. Trad. María Teresa D’Meza. Buenos Aires: Marea, 2012.

Fox-Talbot, William H. F. The pencil of nature. B. Newhall, ed. New York: Da Capo, 1969. 
Mattei, Jean-François. La puissance du simulacre. Dans les pas de Platon. Paris: François Bourin éditeur, 2013.

Platón. Le Sophiste. Oeuvres complètes, tome VIII, troisième partie. Texte établi et traduit par Auguste Diès. Paris: Les Belles Lettres, 2003 a.

— La République. Oeuvres complètes, tome VII, deuxième partie. Texte établi et traduit par Émile Chambry. Paris: Les Belles Lettres, 2003b.

Taylor, Roger. Impressed by light. British photographs from paper negatives, 18401860. New York: The Metropolitan Museum of Art, New York, 2007.

Tomás de Aquino. Commentaire du Traité de l'Âme d'Aristote. Introduction, traduction et notes par Jean-Marie Vernier. Paris: J. Vrin, 2007. 